ORIGINAL ARTICLE

\title{
Influence of packaging on the quality of Brazil nuts
}

\author{
Alexandre LORINI ${ }^{1}$, Carmen WOBETO²*, Claudineli Cássia Bueno da ROSA³, Tatiane Andressa HATEM ${ }^{3}$, \\ Sílvia de Carvalho Campos BOTELHO ${ }^{4}$ \\ Universidade Federal de Pelotas, Departamento de Ciência e Tecnologia de Alimentos, Pelotas - RS, Brasil \\ 2 Universidade Federal de Mato Grosso, Instituto de Ciências Naturais, Humanas e Sociais. Avenida Alexandre Ferronato, 1200 CEP 78.557-267, Sinop - MT, Brasil \\ 3 Universidade Federal de Mato Grosso, Instituto de Ciências Agrárias e Ambientais. Avenida Alexandre Ferronato, 1200 CEP 78.557-267, Sinop - MT, Brasil \\ 4 Embrapa Agrossilvipastoril. Rodovia dos Pioneiros MT 222, km 2,5. Zona Rural, CEP 78.550-970 Sinop, MT, Brasil \\ * Corresponding author: carmenwobeto2014@gmail.com
}

\section{ABSTRACT}

The Brazil nut is an important commodity that grows in the Amazon rainforest and is notable for its high nutritional value. However, the effect that packaging has on product shelf-life is unclear. This study evaluated the microbiological and nutritional quality of unshelled Brazil nuts packed in (a) nylon and polypropylene under vacuum, and (b) in polyethylene terephthalate and polyethylene aluminized films. The nuts were stored for nine months under natural environmental conditions. The most probable number of total and thermotolerant coliforms and Escherichia coli, and counting of molds and yeast were determined in the unshelled nuts shortly after collection and every three months during storage. Moisture, lipids, ash, neutral detergent fiber, and acid detergent fiber contents were measured by the gravimetric method. Crude protein content was measured using the Kjeldahl method. Coliform levels were within legislated standards in both types of packaging. Mold and yeast growth increased with time in both types of packaging $\left(0.1 \times 10^{1}\right.$ to $9.5 \times 10^{3}$ colony forming units $\left.\mathrm{g}^{-1}\right)$, but only nuts packaged in aluminum film showed a significant increase after six months of storage. After nine months of storage, both types of packaged nuts had good nutritional quality. Aluminized packaging resulted in better conservation of the lipid fraction and lower permeability to water vapor, however, vacuum packaging was more effective in controlling fungal growth, possibly due to the lack of oxygen.

KEYWORDS: Bertholletia excelsa, storage, nutritional composition, coliform, molds and yeast

\section{Influência da embalagem na qualidade de castanhas-do-brasil}

\section{RESUMO}

As castanhas-do-brasil são um importante produto da floresta amazônica e destacam-se pelo seu alto valor nutricional. Contudo, os efeitos da embalagem sobre a vida de prateleira das castanhas não estáo completamente esclarecidos. Sendo assim, neste estudo, avaliou-se a qualidade microbiológica e nutricional de castanhas-do-brasil descascadas, embaladas em (a) nylon mais polipropileno a vácuo e (b) filmes aluminizados de polietileno tereftalato (PET) e polietileno (PE). As castanhas foram armazenadas por um período de nove meses, sob condiçôes ambientais naturais. Logo após a coleta, e a cada três meses, foram determinados nas castanhas o número mais provável de coliformes totais, coliformes termotolerantes e Escherichia coli, e contagem total de bolores e leveduras. Também foram medidos os teores de umidade, lipídeos, cinzas, fibra em detergente neutro e fibra em detergente ácido por métodos gravimétricos, e os teores de proteína bruta por meio do método de Kjeldahl. Os níveis de coliformes termotolerantes estiveram dentro dos padrôes da legislação nos dois tipos de embalagem. A incidência de bolores e leveduras aumentou ao longo do tempo nas duas embalagens (de $0,1 \times 10^{1}$ a $9,5 \times 10^{3}$ unidades formadoras de colônia; UFC $\mathrm{g}^{-1}$ ), porém somente a embalagem aluminizada apresentou aumento significativo após seis meses de armazenamento. Após nove meses, as castanhas nas duas embalagens apresentaram boa qualidade nutricional, porém a embalagem aluminizada apresentou melhor conservação da fração lipídica e menor permeabilidade a vapores de água. Contudo, a embalagem a vácuo foi mais eficiente no controle do crescimento de fungos, possivelmente devido à ausência de oxigênio.

PALAVRAS-CHAVE: Bertholletia excelsa, armazenamento, qualidade nutricional, coliformes, bolores e leveduras

CITE AS: Lorini, A.; Wobeto, C.; Rosa, C.C.B. da; Hatem, T.A.; Botelho, S. de C.C. 2018. Influence of packaging on the quality of Brazil nuts. Acta Amazonica 48: 368-372. 


\section{INTRODUCTION}

The production of Brazil nuts (Bertholletia excelsa H.B.K) is an important form of sustainable use of natural resources in the Amazon biome (Wadt et al. 2008). The main producing states in Brazil are Acre, Amazonas, Pará, and, to a lesser extent, Mato Grosso. In 2014, Mato Grosso produced 1,820 tons of food products from the forest, including 1,524 tons of Brazil nuts (IBGE 2015), indicating that the Amazonian part of Mato Grosso has considerable potential for non-timber extraction activities.

The low level of technology used in Brazil nut havest and storage imposes limitations to production. The manual harvest in the field can include fruit capsules from the previous crop, and drying takes place under unsuitable conditions by exposing the fruit on unpaved ground, which can result in the early contamination of the seeds inside the woody fruit capsule, mainly by aflatoxin-producing fungi (Souza et al. 2004; Pimentel et al. 2010; Freitas-Silva and Venâncio 2011; Nogueira et al., 2014).

Control of fungal growth, as well as the reduction of the oxidative lipid fraction and nutritional conservation of the product can be achieved by drying and storing the unshelled seeds in appropriate packages (Scussel et al. 2011; Lin et al. 2012). The characteristics of the food product need to be considered when choosing a form of packaging. Respiration remains active in the nuts after harvest, which leads to lipid oxidation, because the nuts contain high levels of polyunsaturated lipids.

Thus, packaging should provide a suitable barrier to water vapor, oxygen and ultraviolet radiation (Brackmann et al. 2002; Lin et al. 2012; Scussel et al. 2013). Aluminum lamination processing in polyethylene terephthalate (PET) or polypropylenebased packages have shown promising results in reducing the permeability to water vapor and oxygen, and as a barrier to ultraviolet radiation (Mueller et al. 2012). In addition, the presence of a nylon layer in polypropylene films provides more resistance to the material, which is desirable in vacuum packaging, but may lead to an increase in water vapor permeability, since nylon is hygroscopic (Fabris et al. 2006; Kim et al. 2014).

Various types of packaging are used in Brazil for storage of unshelled Brazil nuts, however, the effects of different forms of packaging on the shelf life of the nuts have not yet been formally tested. Therefore, this study assessed the microbiological and nutritional quality of unshelled Brazil nuts over nine months in two types of packaging: (a) polypropylene plus nylon vacuum packaging, and (b) PET plus polyethylene (PE) aluminized packaging.

\section{MATERIAL AND METHODS}

The study was conducted at the Food Technology Laboratory of the Federal University of Mato Grosso, Sinop campus, from August 2013 to May 2014. Brazil nuts were acquired in one lot from a local processing company. The nuts were unshelled, but still retained the thin brown pelicule that covers the seed.
The nuts were stored at room temperature, to provide a similar environment to that of domestic food markets in northern Brazil. The temperature and relative humidity of the storage room were measured every hour. The nuts were stored in individual packages of $250 \mathrm{~g}$ with two types of packaging: (a) polypropylene plus nylon vacuum packaging, and (b) PET plus polyethylene (PE) aluminized packaging. The PET and PE aluminized film packaging had a film thickness of $12 \mu \mathrm{m}$ and an aluminum film thickness of 0.03 to $0.06 \mu \mathrm{m}$. The nylon-PE packaging was $100 \mu \mathrm{m}$ thick. Microbiological and physicochemical analyses were performed on the nuts at four control points during the nine-month period: immediately after acquisition from the processing company (time 0 ) and at three, six, and nine months of storage. At each control point, three packages of each type of packaging were opened and the whole content of each package (250 g of nuts) was used for analyses.

\section{Microbiological analysis}

The most probable numbers (MPNs) of total and thermotolerant coliforms and Escherichia coli were measured with the multiple tube technique using three serial dilutions by inoculating $1 \mathrm{ml}$ aliquots of each dilution into three tubes containing Lauryl tryptose broth. For each gassing tube, a loopful of suspension was transferred to a Brilliant green lactose bile broth and Escherichia coli broth tube. Both were incubated at $35^{\circ} \mathrm{C}$ (Kornacki and Johnson 2001).

Standard plate counts of filamentous fungi and yeast were performed using the standard counting method on plates inoculated by the surface spreading of $0.1 \mathrm{~mL}$ aliquots of dilutions of Dichloran 18\% Glycerol (DG18) agar with subsequent incubation at $25^{\circ} \mathrm{C}$ for 5 days (Beuchat and Cousin 2001).

\section{Physical and chemical analyses}

The nuts were ground in a model LTA-2 high-speed industrial blender (Becker, Santa Catarina, Brazil). The resulting product was sieved using a size 20 mesh and stored in polyethylene bags in the refrigerator until all analyses were carried out. The physicochemical analyses were performed in accordance with the methodology described by the Adolfo Lutz Institute (2008). The Van Soest method described by Silva and Queiroz (2009) was used for the determination of acid detergent fiber (ADF) and neutral detergent fiber (NDF).

For the determination of moisture content, the gravimetric method was used with samples held at $105^{\circ} \mathrm{C}$ until constant weight was achieved. Lipid content was determined using approximately $9.5 \mathrm{~g}$ of dried sample maintained in a Soxhlet extraction system for 4 hours at $80^{\circ} \mathrm{C}$ using hexane as solvent. Ash content was determined from the dry and defatted sample, using a muffle furnace at $550{ }^{\circ} \mathrm{C}$ to constant weight. Crude protein levels were measured using the Kjeldahl method. A conversion factor of 5.46 was used to calculate the total 
nitrogen transformation in crude protein. The amount of ADF and NDF in nuts was measured using acid and neutral detergent solutions in the Van Soest method (Silva and Queiroz 2009).

\section{Statistical analysis}

The experiment followed a completely randomized $2 \times 4$ factorial design (two packaging types and four control points during the storage period) with three replicates per treatment. The mean values of the analyzed variables were compared among storage periods with the Scott-Knott grouping test ( $\mathrm{p}$ $\leq 0.05$ ) using the Sisvar software (Ferreira 2011).

\section{RESULTS}

Environmental data within the storage room varied from 22 to $28{ }^{\circ} \mathrm{C}$, and from 53 to $88 \%$ relative humidity, with highest values recorded from October 2013 to February 2014, corresponding to the second to sixth months of storage.

The levels of total and thermotolerant coliforms were within the standards established by Brazilian legislation $(<$ $3 \mathrm{MPN} \mathrm{g}^{-1}$ ) in the two types of packaging during the nine months of storage (ANVISA 2001). The number of colony forming units (CFU) varied from $0.1 \times 10^{1}$ to $1.9 \times 10^{4} \mathrm{CFU}$ $\mathrm{g}^{1}$ in the aluminized film packaging, and from $0.1 \times 10^{1}$ to $9.5 \times 10^{3} \mathrm{CFU} \mathrm{g}^{-1}$ in the vacuum packaging. Only nuts in aluminum packaging showed a significant increase in CFU after six months of storage (Figure 1).

For nuts in aluminized packaging the Scott-Knott test indicated that $\mathrm{ADF}$ values were significantly higher at three, six and nine months in comparison with initial measurements, while NDF values were higher at three and nine months. Vacuum packaged nuts displayed a significant increase in NDF content, which was significantly higher at nine months in comparison with previous measurements (Figure 2). The

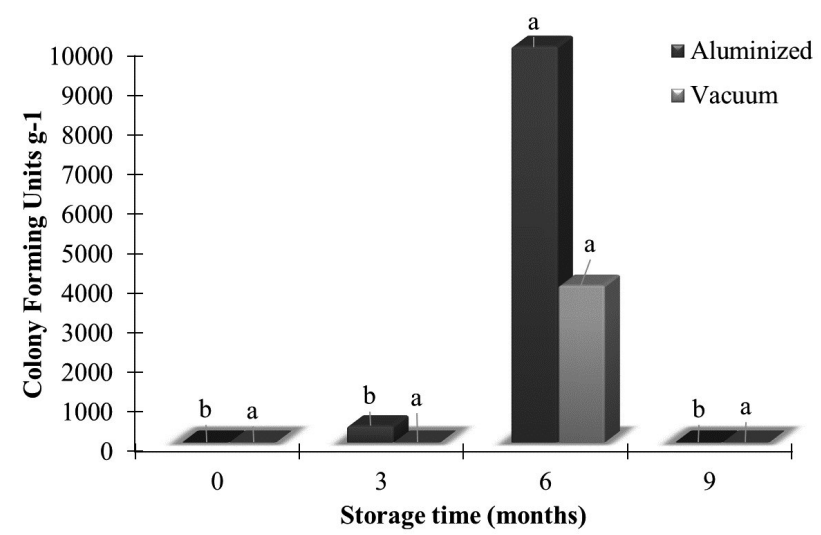

Figure 1. Viable count (colony forming units) of fungi in shelled Brazil nuts in two types of packaging (polypropylene plus nylon vacuum packaging, and PET plus polyethylene aluminized packaging) over a 9-month storage period. Same letters above the columns for each type of packaging indicate the lack of statistical difference among means according to the Scott-Knott test ( $p \leq 0.05)$. levels of ash, moisture and crude protein did not change significantly throughout the storage period in both types of packaging (Figure 2). The total lipid content of nuts in vacuum packaging was significantly higher at three, six and nine months in comparison with initial measurements, while no significant variation was observed for this variable in aluminized packaging (Figure 3).

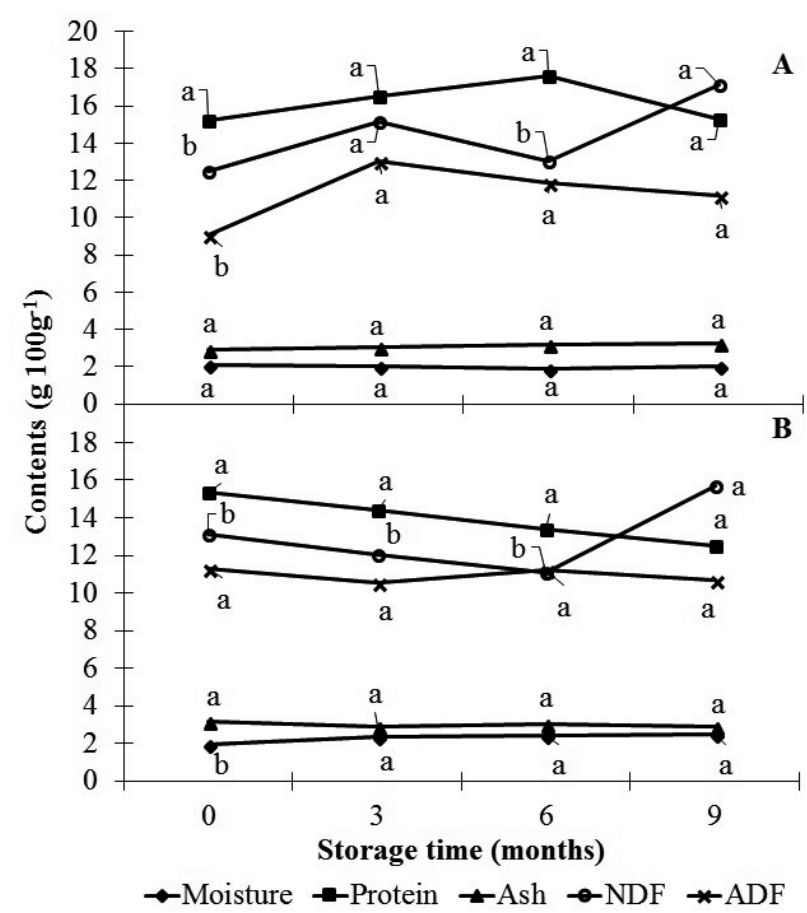

Figure 2. Chemical composition of unshelled Brazil nuts during a 9-month storage period. (A) Nuts in PET plus polyethylene aluminized packaging; (B) Nuts in polypropylene plus nylon vacuum packaging. Same letters above the value points of each variable line indicate the lack of statistical difference among means according to the Scott-Knott test ( $p \leq 0.05)$.

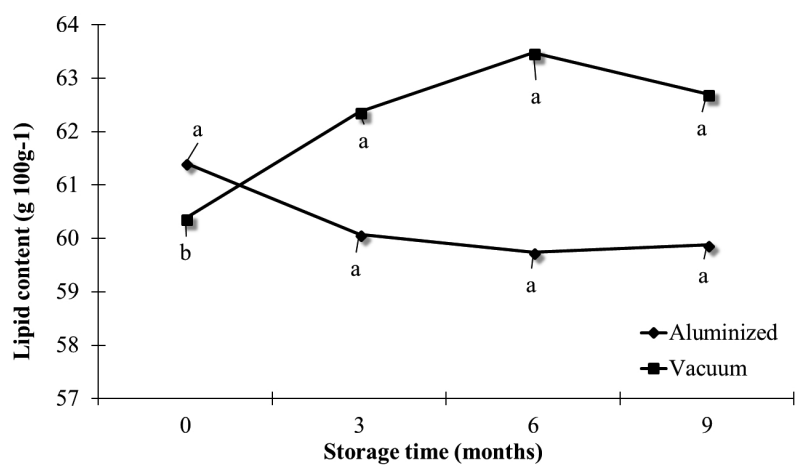

Figure 3. Average levels of lipids in unshelled Brazil nuts during a 9-month storage period in PET plus polyethylene aluminized packaging; and polypropylene plus nylon vacuum packaging. over storage time. Averages followed by the same letter for each packaging type did not differ significantly by the Scott-Knott test $(p \leq 0.05)$. 


\section{DISCUSSION}

Although no significant coliform bacteria growth was observed in the stored Brazil nuts, there was mold growth, which indicates inadequate hygienic conditions (ICMSF 2005). The lower presence of fungi in the vacuum packaging was likely owed to that fungi are aerobic organisms, therefore the absence of oxygen in the plastic packaging under vacuum was more effective in controlling the multiplication of these microorganisms (Jay 2005) in comparison to the aluminized packaging, which allowed oxygen diffusion. The growth of fungi after three to six months of storage was possibly related by the high relative humidity during the study period, since the packages were not totally impermeable to water vapor (Kim et al. 2014). The infiltration of water vapor was more noticeable in the plastic packaging under vacuum in comparison with the aluminized packaging, as evident by the moisture content determinations (see Figure 2). Other studies have also described a reduced permeability to water vapor due to an aluminized layer on PE films, PET, or biaxially oriented polypropylene (Bouquerel et al. 2012; Mueller et al. 2012).

The increase in ADF and NDF contents was probably related to the retention of the brown pelicule adhered to the seeds after unshelling, since the pelicule is the component of the seed richest in fiber (Souza and Menezes 2004).

An increase in the lipid fraction during storage, as observed in our vacuum packaged nuts, was also observed in araucaria (Araucaria angustifolia) seeds (Ramos and Souza 1991) and unshelled hazelnuts stored at room temperature over 12 months, with initial total lipid content of 61.28 $\mathrm{g}$ per $100 \mathrm{~g}$, which increased to, 63.78 at eight months, and 62.69 at 12 months (Ghiraradello et al. 2013). Scussel et al. (2011) observed a positive effect of plastic vacuum packaging on the stability of lipids in unshelled Brazil nuts stored for two months, with a slight increase in peroxide content after one month and stabilization after two months. The differences observed in the behavior of the lipid fraction in vacuum packaged nuts in our study may be related to the longer storage period. The aluminized packaging was effective in reducing lipid fraction reactions in the nuts, probably due to providing a barrier to light, which triggers lipid oxidation (Araújo 2015).

Our results suggest that both types of packaging tested can be used for adequate storage of unshelled Brazil nuts, since the levels of moisture and nutrients in both cases were similar to average levels reported in other studies for unshelled Brazil nuts - 2.00 to $3.15 \mathrm{~g}$ per $100 \mathrm{~g}$ for moisture; 61.00 to $67.30 \mathrm{~g}$ per $100 \mathrm{~g}$ for lipids; 14.29 to $15.60 \mathrm{~g}$ per $100 \mathrm{~g}$ for crude protein; and 3.13 to $3.84 \mathrm{~g}$ per $100 \mathrm{~g}$ for ash (Souza and Menezes 2004; Ferreira et al. 2006; Álvares et al. 2012; Souza 2013).

\section{CONCLUSIONS}

Unshelled Brazil nuts stored in aluminized film or polypropylene under vacuum during nine months showed good nutritional quality. Additionally, nuts stored in vacuum packaging showed a lower fungal count during storage.

\section{ACKNOWLEDGMENTS}

The authors are grateful to Fundação de Amparo à Pesquisa de Mato Grosso (FAPEMAT) for financial support.

\section{REFERENCES}

Álvares, V.S.; Castro, I.M.; Costa, D.A.; Lima, A.C.; Madruga A.L.S. 2012. Qualidade da castanha-do-brasil do comércio de Rio Branco, Acre. Acta Amazonica, 42: 269-274.

ANVISA. 2001. Resoluçấo no12 de 02 de janeiro de 2001. Regulamento técnico sobre padróes microbiológicos para alimentos. Agência Nacional de Vigilância Sanitária, Brasil, Ministério da Saúde, Brasil.

Araújo, J.M.A. 2015. Quimica de alimentos - teoria e prática. 6th. ed. Editora UFV, Viçosa, 478p.

Bouquerel, M.; Duforestel, T.; Baillis, D.; Rusaouen, G. 2012. Mass transfer modelingin gas barrier envelopes for vacuum insulation panels: a review. Energy and Buildings, 55: 903-920.

Beuchat, L.R,; Cousin, M.A. 2001. Yeasts and models. In: Downes, F.P.; Ito, K. (Ed.). Compendium of Methods for the Microbiological Examination of Foods. Apha, Washington, p.209-215.

Brackmann, A.; Neuwald, D.A.; Ribeiro, N.D.; Freitas, S.T. de. 2002. Conservation of three bean genotypes (Phaseolus vulgaris $\mathrm{L}$.) of the group carioca in cold storage and controlled atmosphere. Revista Ciência Rural, 32: 911-915.

Fabris, S., Freire, M.T.A.; Reyes, F.G.R. 2006. Embalagens plásticas: tipos de materiais, contaminação de alimentos e aspectos de legislação. Revista Brasileira de Toxicologia, 19: 59-70.

Ferreira, D.F. 2011. Sisvar: a computer statistical analysis system. Revista Ciência e Agrotecnologia, 35: 1039-1042.

Ferreira, E.S.; Silveira, C.S.; Lucien, V.G.; Amaral, A.S. 2006. Caracterização físico-química da amêndoa, torta e composição dos ácidos graxos majoritários do óleo bruto da castanha-do-brasil (Bertholletia excelsa H.B.K). Alimentos e Nutrição, 17: 203-208.

Freitas-Silva, O.; Venâncio, A. 2011. Brazil nuts: Benefits and risks associated with contamination by fungi and mycotoxins. Food Research International, 44: 1434-1440.

Ghirardello, D.; Contessa. C.; Valentini, N.; Zeppa, G; Rolle, L.; Gerbi, V.; Bott, R. 2013. Effect of storage conditions on chemical and physical characteristics of hazelnut (Corylus avellana L.). Postharvest Biology and Technology, 81: 37-43.

Instituto Adolfo Lutz. 2008. Métodos físico-químicos para análise de alimentos. 4th ed. Instituto Adolfo Lutz, São Paulo, 2478p.

IBGE. 2015. Sistema IBGE de Recuperação Automática - SIDRA. Produção da extração vegetal e da silvicultura. Instituto Brasileiro de Geografia e Estatística. (http://www.sidra.ibge.gov.br/bda/

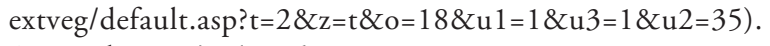
Accessed on 12/03/2016. 
ICMSF. 2005. Microorganisms in foods. v. 2. International Commission of Microbiological Specifications for Foods. Academic Press, New York, 777p.

Jay, J.M. 2005. Microbiologia de alimentos. 6th ed. Artmed, Porto Alegre, 896p.

Kim Y.T.; Min, B.; Kim, K.W. 2014. General characteristics of packing materials for food systems. In: Han, J.H. (Ed.). Innovations in food packing. 2nd ed. Academic Press, Plano, USA, p.13-35.

Kornacki. J.L.; Johnson, J.L. 2001. Enterobacteriaceae, coliforms, and Escherichia coli as quality and safety indicators. In: Downes, F.P.; Ito, K. (Ed.). Compendium of Methods for the Microbiological Examination of Foods. Apha, Washington, p.69-80.

Lin, X.; Wu, J.; Zhu, R.; Chen, P.; Huang, G.; Li, Y.; et al. 2012. California almond shelf life: lipid deterioration during storage. Journal of Food Science, 77: C583-C593.

Mueller, B.K.; Schoenweitz, C.; Langowski, H.C. 2012. Thin laminate films for barrier packaging application - influence of down gauging and substrate surface properties on the permeation properties. Packaging Technology and Science, 25: 137-148.

Nogueira, R.M.; Álvares, V.S.; Ruffato, S.; Lopes, R.P.; Silva, J.S. 2014. Physical properties of Brazil nuts. Journal of the Brazilian Association of Agricultural Engineering, 34: 963- 971.

Pimentel, F.A.; Cardoso, M.G.; Batista, L.R.; Guimarães, L.G.; Silva, D.M. 2010. Açáo fungitóxica do óleo essencial de Tanaecium nocturnum (Barb. Rodr.) Bur. e K. Shum sobre o Aspergillus flavus isolado da castanha-do-Brasil (Bertholletia excelsa). Acta Amazonica, 40: 213-220.

Ramos, A.; Souza, G.B. 1991. Utilização das reservas alimentícias de sementes de Araucária durante armazenamento. Boletim de Pesquisa Florestal, 22: 21-27.
Scussel, V.M.; Giordano, B.N.; Simão, V.; Manfio, D.; Galvao, S.; Rodrigues, M.N.F. 2011. Effect of oxygen-reducing atmospheres on the safety of packaged shelled Brazil nuts during storage. International Journal of Analytical Chemistry, 2011: ID 813591.

Silva, D.J.; Queiroz, A.C. 2009. Análise de alimentos: Métodos químicos e biológicos. 3rd ed. Editora UFV, Viçosa, 56p.

Souza, J.M.L. 2013. Caracterizaçáo e efeitos do armazenamento de amêndoas com películas e despeliculadas sobre propriedades das fraçóes proteica e lipídica de castanha-do-brasil. Doctoral thesis, Universidade Federal de Pelotas, Pelotas, Rio Grande do Sul. 134p.

Souza, M.L.; Menezes, H.C. 2004. Processamentos de amêndoa e torta de castanha-do-brasil e farinha de mandioca: parâmetros de qualidade. Revista Ciência e Tecnologia de Alimentos, 24: 120-128.

Souza, J.M.L.; Cartaxo, C.B.C.; Leite, F.M.N.; Souza, L.M. 2004. Manual de Segurança e Qualidade para a Cultura da Castanha do Brasil. Série Qualidade e Segurança dos Alimentos. Embrapa, Brasília, DF. 48 p. (http://www.agencia.cnptia.embrapa.br/Repositorio/ Manual+castanha_000g2hia5yh02wx5ok0ghx3a9j5yyj4v.pdf). Accessed on 25/02/2015.

Wadt, I.H.O.; Kainer, K.A.; Staudhammer, C.L.; Serrano, R.O.P. 2008. Sustainable forest use in Brazilian extractive reserves: natural regeneration of Brazil nut in exploited populations. Biological Conservation, 141: 332-346.
RECEIVED: 05/06/2017
ACCEPTED: 01/06/2018
ASSOCIATE EDITOR: João Paulo Silva 